\title{
TINJAUAN YURIDIS TENTANG EFEKTIVITAS JUDICIAL REVIEW OLEH MAHKAMAH KONSTITUSI DIHUBUNGKAN DENGAN UNDANG-UNDANG NOMOR 8 TAHUN 2011 TENTANG MAHKAMAH KONSTITUSI
}

\author{
Otto Restu Fadjar ${ }^{1}$ \\ E-mail:restu99@gmail.com
}

\begin{abstract}
ABSTRAK
Mahkamah Konstitusi tugas dan kewenangan yang diembannya di Negara Republik Indonesia sebagai bagian dari pelaksana kekuasaan kehakiman, adalah melakukan Judicial Review terkait pengujian konstitusionalitas Undang-Undang terhadap Undang-Undang Dasar Negara Republik Indonesia Tahun 1945. Hanya saja dalam praktiknya model pengaturan yang demikian justru rentan menimbulkan sejumlah persoalan hukum. Contohnya, kewenangan Mahkamah Konstitusi ternyata justru berpeluang untuk mematahkan atau menggugurkan putusan-putusan perkara judicial review yang berada di Mahkamah Agung dalam perkara yang saling berkaitan.

Metode yang penulis gunakan pada pendekatan ini adalah Pendekatan secara Yuridis Normatif yaitu pendekatan atau penelitian hukum dengan menggunakan metode pendekatan/teori/konsep dan metode analisis yang termasuk dalam disiplin ilmu hukum dogmatis

Pelaksanaan Putusan MK Nomor 09/PUU-VII/2009 dan Putusan MK Nomor 24/PUU-XII/2014 tidak efektif dan tidak dapat dilaksanakan sebagaimana mestinya. Akibat ketidak patuhan atau tidak efektivnya Putusan Mahkamah Konstitusi dengan kembali berlakunya ketentuan pasal-pasal yang diuji oleh Mahkamah Konstitusi tersebut menyebabkan ketidakpastian hukum. Putusan Mahkamah Konstitusi Nomor 24/PUU-XVII/2019 yang menyatakan bahwa materi muatan ayat, pasal dan/atau bagian undang-undang bertentangan dengan Undang-Undang Dasar Negara Republik Indonesia Tahun 1945, maka materi muatan ayat, pasal dan/atau bagian undang-undang tersebut tidak mempunyai kekuatan hukum mengikat. Karena tidak ada kejelasan tujuan tentang ayat, pasal dan/atau bagian undang-undang tersebut.
\end{abstract}

Kata Kunci : Mahkamah Konstitusi, judicial review, Putusan Mahkamah Konstitusi, Undang-Undang, Undang-Undang Dasar Tahun 1945.

\footnotetext{
${ }^{1}$ Dosen Tetap Fakultas Hukum Universitas Majalengka
} 


\section{A. Latar Belakang Masalah}

Salah satu keberhasilan yang telah diperoleh bangsa Indonesia dari perubahan konstitusi khususnya pada saat perubahan ketiga tahun 2001 adalah terkait dengan pengaturan kekuasaan kehakiman yang dijalankan oleh dua lembaga negara yaitu Mahkamah Agung (selanjutnya disebut MA) dan Mahkamah Konstitusi (selanjutnya disebut MK). Berdasarkan ketentuan sebelum perubahan Undang-Undang Dasar Negara Republik Indonesia Tahun 1945, kekuasaan kehakiman hanya dipegang oleh Mahkamah Agung, namun kini kehadiran Mahkamah Konstitusi telah melengkapi fungsi peradilan khususnya terkait dengan penyelesaian masalah-masalah ketatanegaraan. ${ }^{2}$

Dalam Pasal 2 Undang-Undang Nomor 14 Tahun 1985 tentang Mahkamah Agung sebagaimana dirubah menjadi Undang-undang Nomor 3 Tahun 2009 menyatakan Mahkamah Agung adalah Pengadilan Negara Tertinggi dari semua Lingkungan Peradilan, yang dalam melaksanakan tugasnya terlepas dari pengaruh pemerintah dan pengaruh-pengaruh lain. di Indonesia. ${ }^{3}$ Mahkamah Agung merupakan lembaga kekuasaan kehakiman di tingkat peradilan umum yang memutus perkara pidana dan perdata atau permohonan yang tidak menjadi kompetensi lembaga peradilan khusus. ${ }^{4}$

Mahkamah Agung diberikan kewenangan untuk menguji Peraturan Perundang-undangan terhadap undang-undang. Kewenangan judicial review pada dasarnya berfungsi untuk menjadikan bentangan Peraturan Perundangundangan dan Keputusan yang harmoni, sinkron dan tertib antara jenis dan hierarki satu dengan yang lainnya. Artinya antara Pancasila, Peraturan Perundang-undangan dan Keputusan tetap berada pada tertib hukum, dalam arti tidak saling bertentangan. ${ }^{5}$ Dalam Pasal 31A Undang-Undang Nomor 3 Tahun 2009 menegaskan bahwa Permohonan pengujian peraturan perundangundangan di bawah undang-undang terhadap undang-undang diajukan langsung oleh pemohon atau kuasanya kepada Mahkamah Agung.

Mahkamah Agung dapat menguji peraturan perundang-undangan yang disebut judicial review diatur dalam Pasal 20 ayat (2) huruf b dan UndangUndang Nomor 48 Tahun 2009 tentang Kekuasaan Kehakiman. ${ }^{6}$

Selain itu, Mahkamah Konstitusi tugas dan kewenangan yang diembannya di Negara Republik Indonesia sebagai bagian dari pelaksana kekuasaan kehakiman, adalah melakukan Judicial Review terkait pengujian konstitusionalitas Undang-Undang terhadap Undang-Undang Dasar Negara

2 Abdul Latif, Buku Ajar Hukum Acara Mahkamah Konstitusi, Total Media, Yogyakarta, 2009, hlm. 9.

${ }^{3}$ Undang-Undang Nomor 48 Tahun 1985 tentang Mahkamah Agung.

${ }^{4}$ Sihajuddin dan Winardi, Dasar-dasar Hukum Tata Negara Indonesia, Setara Press, Malang, 2015, hlm. 10.

${ }^{5}$ Cahyo Dwi Nugrahanto, Hak Uji Materiil Oleh Kekuasaan Kehakiman (Judicial Review) terhadap Peraturan menteri Oleh Mahkamah Agung Republik Indonesia, diakses dari https://digilib.uns.ac.id/dokumen/download/27657/NTg1MjA=/Hak-Uji-Materiil, pada tanggal 11 November 2019, pukul 12.13.

${ }^{6}$ Sihajuddin dan Winardi, Dasar-dasar Hukum Tata Negara, Op.Cit., hlm. 148. 
Republik Indonesia Tahun 1945 sesuai dengan ketentuan yang terdapat dalam Pasal 24C. ${ }^{7}$

Pengujian yudisial (bahasa Inggris: judicial review) adalah suatu proses ketika tindakan eksekutif dan legislatif ditinjau oleh badan yudikatif. Badan tersebut akan meninjau apakah suatu tindakan atau undang-undang sejalan dengan konstitusi suatu negara. Wewenang untuk meninjau sendiri biasanya diatur oleh konstitusi. Apabila suatu tindakan atau undang-undang dianggap tidak konstitusional, tindakan atau undang-undang tersebut dapat dibatalkan. Maka dari itu, pengujian yudisial merupakan salah satu mekanisme check and balance dalam doktrin pemisahan kekuasaan. ${ }^{8}$

Didalam Pasal 9 ayat (1) dan (2) Undang-Undang Nomor 12 Tahun 2011 Tentang Pembentukan Peraturan Perundang-undangan menyebutkan bahwa apabila suatu Undang-Undang diduga bertentangan dengan UndangUndang Dasar Negara Republik Indonesia Tahun 1945 maka pengujiannya dilakukan oleh Mahkamah Konstitusi, apabila dalam hal suatu Peraturan Perundang-undangan di bawah Undang-Undang diduga bertentangan dengan Undang-Undang maka pengujiannya dilakukan oleh Mahkamah Agung. ${ }^{9}$

Didalam Pasal 10 ayat (1) Undang-Undang Nomor 23 Tahun 2009 sebagaimana dirubah dengan Undang-Undang Nomor 8 Tahun 2011 Tentang Mahkamah Konstitusi, menegaskan hal yang sama bahwa Mahkamah Konstitusi pada tingkat pertama dan terakhir yang putusannya bersifat final, antara lain “.......menguji Undang-Undang terhadap Undang-Undang Dasar Tahun 1945." "10

Dibentuknya Mahkamah Konstitusi adalah dimaksudkan dalam rangka menyempurnakan sistem dan mekanisme serta model kewenangan judicial review di Indonesia. Hanya saja dalam praktiknya model pengaturan yang demikian justru rentan menimbulkan sejumlah persoalan hukum. Contohnya, kewenangan Mahkamah Konstitusi ternyata justru berpeluang untuk mematahkan atau menggugurkan putusan-putusan perkara judicial review yang berada di Mahkamah Agung dalam perkara yang saling berkaitan. ${ }^{11}$

Dalam Putusan Mahkamah Konstitusi Nomor 24/PUU-XVII/2019 terhadap Pengujian Undang-Undang Nomor 7 Tahun 2017 tentang Pemilihan Umum pada Pasal 449 ayat (2), ayat (5), ayat (6), Pasal 509 dan Pasal 540 yang bertentangan dengan Undang-Undang Dasar Negara Republik

\footnotetext{
${ }^{7}$ Ibid., hlm. 9.

${ }^{8}$ Diakses dari https://id.wikipedia.org/wiki/Pengujian_yudisial, diakses pada tanggal 31 Oktober 2019, pukul 14.04.

9 Undang-Undang Nomor 12 Tahun 2011 Tentang Pembentukan Peraturan Perundang-undangan.

10 Putusan Mahkamah Konstitusi Nomor 24/PUU-XVII/2019, diakses dari https://mkri.id/public/content/persidangan/putusan/putusan_mkri_5363.pdf, pada tanggal 02 November 2019, pukul 11.46.

${ }^{11}$ Janpatar Simamora, Analisa Yuridis terhadap Model Kewenangan Judicial Review di Indonesia, diakses dari https://media.neliti.com/media/publications/40754-analisa-yuridisterhadap-model-kewenanga-be76111e.pdf, pada tanggal 02 November 2019, pukul 11.53 .
} 
Indonesia Tahun 1945 khususnya Pasal 28D ayat (1), Pasal 28E ayat (3), dan Pasal 28F tentang Hak Asasi Manusia.

Salah satu contoh Pasal 449 ayat (2) Undang-Undang Nomor 7 Tahun 2017 yang bertentangan dengan Pasal 28D ayat (1) yaitu Pasal 449 ayat (2) Undang-Undang No. 7 Tahun 2007 menyatakan "Pengumuman hasil survei atau jajak pendapat tentang Pemilu sebagaimana dimaksud pada ayat (10 dilarang dilakukan pada masa tenang".

Pasal yang telah disebutkan diatas tidak memiliki landasan konstitusional dan bertentangan dengan prinsip kepastian hukum menurut Putusan Mahkamah Kontitusi Nomor 24/PUU-XVII/2019. Dan berdasarkan Putusan Mahkamah Nomor 09/PUU-VII/2009 bahwa pasal tersebut bertentangan dengan Undang-undang Dasar 1945. Mahkamah Konstitusi melalui Putusan Nomor 24/PUU-XII/2014 pengujian Undang-undang terhadap Undang-Undang Nomor 8 Tahun 2012 mencabut pasal tersebut karena dinyatakan inkonstitusional. Akibat ketidakpatuhan terhadap putusan MK dengan kembai berlakunya Pasal tersebut, maka telah menyebabkan ketikpastian hukum bagi pelaksanaan dan publikasi hasil survei pada masa tenang dan publikasi hasil hitung cepat. ${ }^{13}$

Undang-Undang yang berada di bawah Undang-Undang Dasar Tahun 1945 tidak boleh bertentangan dengan konstitusi baik secara vertikal (menurut Hierarki Peraturan Perundang-undangan di Indonesia) maupun secara horizontal dengan Undang-Undang yang sejenis. Maka dari itu judicial review merupakan salah satu mekanisme check and balance antar lembaga kekuasaan negara.

Paparan latar belakang tersebut menarik untuk dikaji dan analisis oleh penulis dalam bentuk skripsi dengan judul "TINJAUAN YURIDIS TENTANG EFEKTIVITAS JUDICIAL REVIEW OLEH MAHKAMAH KONSTITUSI DIHUBUNGKAN DENGAN UNDANG-UNDANG NOMOR 8 TAHUN 2011 TENTANG MAHKAMAH KONSTITUSI".

\section{B. Identifikasi Masalah}

Berdasarkan uraian di atas, pokok permasalahan yang akan dibahas dalam jurnal ini adalah sebagai berikut:

1. Bagaimana efektivitas judicial review oleh Mahkamah Konstitusi?

2. Sejauh mana kekuatan hukum mengikat keputusan Mahkamah Konstitusi?

\section{Tujuan Penelitian}

Sesuai dengan permasalahan di atas, maka tujuan penelitian ini adalah:

1. Untuk mengetahui efektivitas judicial review oleh Mahkamah Konstitusi

2. Untuk kekuatan hukum mengikat keputusan Mahkamah Konstitusi

\footnotetext{
${ }^{12}$ Putusan Mahkamah Konstitusi Nomor 24/PUU-XVII/2019, Op.Cit.

${ }^{13}$ Ibid.
} 


\section{Kerangka Pemikiran}

\section{Teori Toetsingrecht dan Judicial Review}

Perbedaan pengujian Perundang-undangan terjadi dalam tataran terminologi dan pendekatan tradisi hukum. Secara terminologi, istilah hak menguji dipadankan dengan istilah toetsingrecht yang muncul di Belanda dan dikenal juga di negara-negara civil law. Di negara-negara anglo saxon, istilah yang berkembang adalah judicial review dan constitutional review. Negara-negara anglo saxon tidak mengenal toetsingrecht. Dalam perkembangannya istilah judicial review dan constitutional review juga digunakan di negara-negara civil law seperti Jerman dan Perancis. ${ }^{14}$

Istilah toetsingrecht diartikan sebagai hak atau kewenangan untuk menguji atau hak uji. ${ }^{15}$ Pengertian tersebut memperjelas bahwa istilah toetsingrecht merupakan suatu proses untuk melakukan pengujian atau menguji dan secara harfiah dapat diartikan sebagai kewenangan untuk menguji. ${ }^{16}$

Hak menguji suatu Peraturan Perundang-undangan didasarkan pada organ pengujianya. Hak menguji Peraturan Perundang-undnagan yang diberikan kepada kekuasaan legislatif disebut legislative review. Hak menguji yang diberikan kekuasaan eksekutif disebut dengan executive review. Hak menguji (toetsingrecht) Peraturan Perundang-undangan yang diberikan kepada kekuasaan yudikatif disebut dengan judicial review. ${ }^{17}$

Terdapat dua pengujian yang dilakukan kekuasaan kehakiman yaitu pengujian materiil (berkenaan dengan materi muatan dalam ayat,pasal, dan/atau bagian Undang-Undang yang dianggap bertentangan dengan Undang-Undang Dasar 1945 dan pengujian formil (pengujian yang berkenaan dengan proses pembentukan Undang-Undang). ${ }^{18}$

Antara judicial review dan constitutional review terdapat perbedaan. Secara substansial, judicial review lebih luas dari constitutional review karena constitutional review merupakan bagian dari judicial review. Jika dilihat dari organ pengujinya constitutional review lebih luas dibandingkan judicial review karena constitutional review dilakukan oleh kekuasaan kehakiman melalui judicial review dapat juga dilakukan oleh legistlatif melalui legislative review. ${ }^{19}$

${ }^{14}$ Imam Soebechi, Hak Uji Materiil, Sinar Grafika, Jakarta, 2016, hlm.51.

15 Jimly Asshiddiqie, Model-model Pengujian Konstitusional di Berbagai Negara, Konstitusi Press, Jakarta, 2013, hlm. 6.

${ }^{16}$ M. Laica Marzuki, Berjalan di Ranah Hukum, Konstitusi Press, Jakarta, 2005, hlm. 47.

17 Jimly Asshiddiqie, Hukum Acara Pengujian Undang-Undang, Konstitusi Press, Jakarta, 2006, hlm. 1.

${ }^{18}$ Abi Jam'an Kurnia, Uji Materiil dan Uji Formil, diakses dari www.hukumonline.com, pada tanggal 15 November 2019, pukul 08.35.

${ }^{19}$ Imam Soebechi, Op.Cit., hlm. 52. 


\section{Teori Stufenbauw}

Menurut teori Hans Kelsen karena peraturan perundang-undangan dari tingkat yang rendah tidak boleh bertentangan dengan peraturan perundang-undangan yang lebih tinggi atau yang dikenal dengan teori Stufenbauw ades Recht the Hierarkhy of Law Theory:

"The Legal order... is therefore nota system of norms coordinated to each other, standing, so to speak, side by side on the same level, but a hierarkhy of different levels of norms" (sebuah tata hukum bukanlah merupakan suatu sistem kaidah-kaidah hukum yang berhubungan satu sama lain dalam kedudukan yang sederajat melainkan merupakan berhirarki dari kaidah-kaidah yang berada sederajat). ${ }^{20}$

Apa yang dikemukakan oleh Hans Kelsen di atas menunjukkan kekhawatiran akan timbulnya konflik antara norma yang lebih tinggi dengan norma yang lebih rendah bukan hanya menyangkut hubungan antara Undang-Undang dengan keputusan pengadilan tetapi juga menyangkut antara konstitusi dengan undang-undang. Oleh karena itu, Kelsen mengemukakan sejumlah syarat agar kepatuhan terhadap konstitusi dapat terjamin yakni pertama, adanya organ yang diberi otoritas untuk melakukan pengujian hukum judicial review; dan kedua tersedianya mekanisme atau prosedur termasuk dalam hal ini menyangkut azas-azas dan kaidah-kaidah hukum untuk melakukan pengujian hukum. ${ }^{21}$

\section{Teori Konstitusi}

Istilah konstutusi berasal dari bahasa Inggris yaitu "Constitution" dan berasal dari bahasa Belanda "Constiue", dalam bahasa Latin "contitutio, constituere", dalam bahasa Prancis yaitu "constiture", dalam bahasa Jerman "vertassung" dalam ketatanegraan Republik Indonesia diartikan dengan Undang-Undang Dasar. Konstitusi atau Undang-Undang Dasar dapat diartikan peraturan dasar dan yang memuat ketentuan-ketentuan pokok dan menjadi sumber perundang-undangan. ${ }^{22}$

Kata "Konstitusi" berarti "pembentukan", berasal dari kata kerja yaitu "constituer" (Perancis) atau membentuk. Yang dibentuk adalah negara, maka kosntitusi mengandung makna awal permulaan dari segala peraturan perundang-undangan tentang negara. Belanda menggunakan istilah "Grondwet" yang berarti suatu undnag-undang yang menjadi dasar (grond) dari segala hukum. Dalam bahasa Latin, kata konstitusi merupakan gabungan dua kata, yaitu cume dan statuere. Cume adalah sebuah preposisi yang berarti "bersama dengan...", sedangkan statuere mempunai arti "membuat sesuatu atau mendirikan atau menetapkan". Indonesia menggunakan istilah Grondwet menjadi Undang-Undang Dasar. ${ }^{23}$

${ }^{20}$ Sumali, Reduksi Kekuasaan Eksekutif Di Bidang Peraturan Pengganti UndangUndang (PERPU), UMM Press, Malang, 2002, hlm. 2.

${ }^{21}$ Ibid., hlm. 61.

22 Muhamad Rakhmat, Konstitusi dan Kelembagaan Negara, Logoz Publishing, Bandung, 2014, hlm. 1.

${ }^{23}$ Ibid. 
Faktor-faktor yang mempengaruhi warga negara harus mentaati suatu konstitusi di suatu negara :

a. Pendekatan dari aspek hukum :

1). Konstitusi mengikat, karena ditetapkan oleh badan yang berwenang membentuk hukum, dan konstitusi itu dibuat untuk dan atas nama rakyat (positivisme hukum).

2).Konstitusi mengikat karena konstitusi merupakan alat untuk membatasi kekuasaan negara.

b. Pendekatan dari aspek politik : hukum adalah produk politik yang telah menjadikan badan konstituante sebagai badan pembuat konstitusi, sehingga produk politik yang berupa konstitusi mempunyai daya ikat pemberlakuannya bagi warga negara.

c. Pendekatan dari aspek moral : konstitusi merupakan daya ikat terhadap warga negara karena penetapan konstitusi didasarkan pada nilai-nilai moral (hukum alam), karena moral adalah pengaturan perubahan mandiri dari segi baik dan buruknya. ${ }^{24}$

\section{Teori Perundang-undangan}

Pengertian perundang-undangan dalam hukum positif Indonesia disebutkan dalam Pasal 1 ayat (2) Undang-Undang Nomor 12 Tahun 2011 tentang pembentukan peraturan perudang-undangan, yang menyatakan bahwa "Peraturan Perundang-undangan adalah peraturan tertulis yang memuat norma hukum yang mengikat secara umum dan dibentuk atau ditetapkan oleh lembaga negara atau pejabat yang berwenang melakukan prosedur yang ditetapkan dalam Peraturan Perundang-undangan."

Sesudah berlakunya Undang-Undang Nomor 10 Tahun 2004 yang dirubah menjadi Undang-Undang Nomor 12 Tahun 2011 tentang Pembentukan Peraturan Perundang-undangan diatur dalam Pasal 7 ayat (1) yang terdiri atas :

a. Undang-Undang Dasar Negara Republik Indonesia Tahun 1945;

b. Ketetapan Majelis Permusyawaratan Rakyat;

c. Undang-Undang/Peraturan Pemerintah Pengganti Undang-Undang;

d. Peraturan Pemerintah;

e. Peraturan Presiden;

f. Peraturan Daerah Provinsi;dan

g. Peraturan Daerah Kabupaten/Kota.

Peraturan Daerah yang dimaksud Pasal 7 ayat (1) menurut H. Abdul Latief, meliputi :

a. Peraturan Daerah Provinsi dibuat oleh Dewan Perwakilan Rakyat Daerah Provinsi bersama Gubernur;

b. Peraturan Daerah Kabupaten/Kota dibuat oleh Dewan Perwakilan Rakyat Daerah Kabupaten/Kota bersama Bupati/Walikota;

${ }^{24}$ Diakses dari https://www.slideshare.net/Meehawk/teori-konstitusi-35464074, pada tanggal 26 November 2019, pukul 20.39. 
c. Peraturan Desa/Peraturan yang setingkat, dibuat oleh Badan Perwakilan Desa atau nama lainnya bersama dengan Kepala Desa atau nama lainnya. $^{25}$

\section{Teori Kelembagaan atau Teori Institusional}

Teori Institusional (Institutional Theory) atau teori kelembagaan dasar pikirannya adalah terbentuk organisasi karena tekanan lingkungan institusional yang menyebabkan institusionalisasi. Zikler (1987) dan Donaldson (1995), menyatakan bahwa ide atau gagasan pada lingkungan institusional yang membentuk bahasa dan simbol yang menjelaskan keberadaan organisasi dan diterima (taken for granted) sebagai normanorma dalam konsep organisasi. Teori kelembagaan didasarkan pada asumsi bahwa hasil kolektif dan perilaku individu yang terstruktur oleh lembaga. Teori kelembagaan mencakup literatur lintas disiplin, termasuk cabang di ekonomi, sosiologi, dan ilmu politik. Teori kelembagaan dalam administrasi publik bisa dilihat dalam konsep Birokrasi Klasik.

Dalam demokrasi melalui kedaulatan rakyat, hak menimbulkan wewenang, suatu wewenang yang didukung oleh hukum. Hasilnya adalah sebuah sistem ketertiban yang menjadi landasan yang memungkinkan dijalankannya kekuasaan serta ditetapkannya asas-asas kewajaran atau keadilan. Selanjutnya lembaga-lembaga pemerintahan ini terbagi dalam tiga wewenang, yaitu:

a. Lembaga Legislatif

Lembaga ini merupakan pengawas terpenting terhadap kekuasaan yang nyata maupun potensial. Badan ini terdiri atas wakil-wakil rakyat. Semua pemberlakuan hukum harus disetujui oleh badan legislatif ini.

b. Lembaga Eksekutif

Lembaga eksekutif pemerintah ini bertanggungjawab sesuai dengan makna yang terkandung dalam namanya, yaitu melaksanakan keinginankeinginan rakyat. Dalam sistem demokrasi, eksekutif ini bertindak atas nama rakyat.

\section{c. Lembaga Yudikatif}

Dengan adanya yuridiksi-yuridiksi kekuasaaan yang dibatasi konstitusi dalam hal mana mereka harus saling berhubungan dalam urusan pembuatan kebikjsanaan, selalu ada kemungkinan terjadinya pelanggaran konstitusi. Maka diperlukan adanya pengadilan tinggi yang berfungsi sebagai lembaga untuk masalah-masalah penafsiran konstitusional. ${ }^{26}$ 02 November 2019, pukul 12.56.

${ }^{26}$ Tanicha Aprilia dan Ditho Nugraha, Lembaga Negara Fungsi dan Wewenangnya, diakses dari http://kuliahpublik.blogspot.com/2015/04/teori-institusional.html, pada tanggal 11 November 2019, pukul 20.10. 


\section{Teori Lembaga Mahkamah Konstitusi}

Merujuk pada sejarah pembentukan Mahkamah Konstitusi, maka hal yang menjadi acuan data penunjang pada awal Negara kita berdiri atau merdeka di kalangan pendiri negara telah merumuskan suatu lembaga kenegaraan seperti Mahkamah Konstitusi. ${ }^{27}$ Kala itu berlangsung perdebatan antara M. Yamin dan Soepomo tentang perlunya Mahkamah Agung diberikan kewenangan menguji materiil Undang-Undang yang dipandang bertentangan dengan Undang-Undang Dasar. ${ }^{28}$

Seiring dengan terjadinya perubahan atau amandemen terhadap Undang-Undang Dasar Tahun 1945 sebagai Konstitusi Negara Republik Indonesia, dinamika ketatanegaraan Indonesia semakin berkembang. Sejarah berdirinya lembaga Mahkamah Konstitusi diawali dengan diadopsinya ide Mahkamah Konstitusi dalam amandemen konstitusi yang dilakukan oleh Majelis Permusyawaratan Rakyat. ${ }^{29}$

Perubahan ketiga Undang-Undang Dasar Tahun 1945 juga mengadopsi pembentukan Mahkamah Konstitusi sebagai lembaga yang berdiri sendiri di samping Mahkamah Agung dengan kewenangan yang diuraikan dalam Pasal 24C ayat (1) dan ayat (2) Undang-Undang Dasar Tahun 1945. Mahkamah Konstitusi adalah lembaga tinggi negara dalam sistem ketatanegaraan Indonesia yang merupakan pemegang kekuasaan kehakiman bersama-sama dengan Mahkamah Agung. ${ }^{30}$

Pembentukan Mahkamah Konstitusi diperlukan untuk menegakkan prinsip negara hukum Indonesia dan prinsip Konstitusionalisme. ${ }^{31}$

\section{E. Metode Penelitian}

Metode dalam penelitian ini dibagi dalam beberapa jenis, diantaranya sebagai berikut :

1. Spesifikasi Penelitian

Spesifikasi penelitian ini adalah deskriptif-analisis, yaitu menggambarkan permasalahan yang berkaitan dengan objek penelitian dan terhadap masalah tersebut kemudian dianalisis.

2. Metode Pendekatan

Metode yang penulis gunakan pada pendekatan ini adalah Pendekatan secara Yuridis Normatif yaitu pendekatan atau penelitian

27 Khunti Dyah Wardani, Impechment Dalam Konstitusi Indonesia, UII Press, Yogyakarta, diakses dari https://dspace.uii.ac.id, pada tanggal 18 November 2019, pukul 21.28.

28

http://www.mahkamahkonstitusi.go.id/index.php?page=web.ProfilMKid=1, pada tanggal 18 November 2019, pukul 21.45.

29 Ibid.

${ }^{30}$ Diakses dari https://id.m.wikipedia.org, pada tanggal 18 November 2019, pukul 21.46 .

31 Khunti Dyah Wardani, Impechment Dalam Konstitusi Indonesia, diakses dari https://dspace.uii.ac.id, Loc.Cit. 
hukum dengan menggunakan metode pendekatan/teori/konsep dan metode analisis yang termasuk dalam disiplin ilmu hukum dogmatis. ${ }^{32}$

3. Tahap Penelitian

Dalam penulisan skripsi ini penulis menggunakan tahap penelitian dengan studi kepustakaan. Studi kepustakaan merupakan penelitian utama, sedangkan penelitian lapangan hanya bersifat penunjang terhadap data kepustakaan. ${ }^{33}$

4. Teknik Pengumpulan Data

Penelitian ini dilakukan dengan teknik pendekatan yuridisnormatif, teknik pengumpulan data yang dapat dilakukan melalui penelaahan data yang dapat diperoleh dalam peraturan perundangundangan, buku, teks, jurnal, hasil penelitian, ensiklopedi, blibliografi, indeks data dengan pendekatan ini dilakukan terhadap berbagai literatur (kepustakaan). ${ }^{34}$

5. Analisis Data

Analisis data yang penulis gunakan adalah Deskriptif Kualitatif, yaitu penganalisian bertitik tolak dari analisis yuridis sistematis. Pada bagian ini alat analisis yang digunakan, yaitu silogisme hukum, interpretasi hukum, dan konstruksi hukum. ${ }^{35}$

\section{F. Hasil Penelitian dan Pembahasan}

1. Efektivitas Judicial Review Undang-Undang Nomor 7 Tahun 2017 tentang Pemilihan Umum oleh Mahkamah Konstitusi

Kewenangan yang diberikan kepada Mahkamah Konstitusi yaitu menguji Undang-undang terhadap Undang-undang Dasar Tahun 1945 dimana ayat, pasal dan/atau bagian Undang-undang yang hendak diuji dianggap bertentangan dengan Konstitusi. Namun, terjadinya pelanggaranpelanggaran oleh lembaga pembentuk undang-undang dimana terdapat ayat, pasal dan/atau bagian undang-undang Nomor 7 Tahun 2017 tentang Pemilu yang telah dicabut melalui Putusan MK Nomor 09/PUU-VII/2009 dan Putusan MK Nomor 24/PUU-XII/2014 yang diberlakukan kembali oleh DPR.

Putusan MK tersebut menyebutkan bahwa ayat,pasal dan/atau yang diajukan dan menjadi permohonan pemohon merupakan inkonstitusional, dikarenakan tidak ada kejelasan tujuan tersebut dan tidak ada dasar hukum yang mengatur berlakunya ayat, pasal dan/atau bagian undang-undang tersebut.

\footnotetext{
${ }^{32}$ Ronny Hanitijo Soemitro dikutip oleh Elviandri, Metodologi Penelitian Hukum dan Jurimetri, Ghalia Indonesia, Jakarta, 1990, http://eprints.ums.ac.id/6751/1/R100040049.pdf, diakses di internet pada tanggal 31 Oktober 2019, pada pukul 15.33.

33 Fakultas Hukum Universitas Majalengka, Panduan Skripsi, Fakultas Hukum Universitas Majalengka, Majalengka, 2019, hlm. 20.

${ }^{34}$ Ibid., hlm. 20-21.

35 Untuk definisi dan pengertian masing-masing analisis sebagaimana dijelaskan di atas, hendaknya dilihat buku rujukan yang menjelaskan persoalan tersebut, misalnya, Buku Ahmad Ali, Menguak Tabir Hukum, Gunung Agung, Jakarta.
} 
Akibat ketidakpatuhan atau tidak efektivnya Putusan Mahkamah Konstitusi dengan kembali berlakunya ketentuan pasal-pasal yang diuji oleh Mahkamah Konstitusi tersebut menyebabkan ketidakpastian hukum bagi pelaksanaan dan publikasi hasil survei pada masa tenang dan publikasi hasil hitung cepat.

Mahkamah Konstitusi dalam menguji undang-undang terhadap Undang-Undang Dasar Negara Republik Indonesia Tahun 1945 dan tidak menggunakan undang-undang lain sebagai dasar pertimbangan hukum. Mahkamah Konstitusi hanya menguji undang-undang dimana ayat,pasal dan/atau bagian yang menjadi permohonan dianggap bertentangan dengan konstitusi, dimana konstitusi sebagai hukum tertinggi dalam hierarki peraturan perundang-undangan. Lembaga pembentuk peraturan perundangundangan harus mengacu kepada konstitusi, apabila undang-undang tersebut inkonstitusional maka dianggap lembaga legislatif melakukan perbuatan melawan hukum.

Bagi lembaga Legislatif atau DPR selaku lembaga pembentuk undang-undang hendaknya tidak melakukan pengabaian terhadap Putusan MK sebelumnya. Naskah Akademik Undang-undang Nomor 7 Tahun 2017 tentang pemilu tidak menjadikan Putusan MK Nomor 09/PUUVII/2009 dan Putusan MK Nomor 24/PUU-XII/2014 untuk melakukan analisa dan evaluasi yuridis. DPR telah melanggar Pasal 5 point (a) Undang-undang Nomor 12 Tahun 2011 dimana terdapat asas pembentukan peraturan perundang-undangan yang baik meliputi asas kejelasan tujuan artinya bahwa setiap pembentukan peraturan perundangundangan harus mempunyai tujuan yang jelas yang hendak dicapai.

DPR telah melanggar Pasal 6 ayat (1) Undang-undang Nomor 12

Tahun 2011 tentang Peraturan Perundang-Undangan, yaitu asas ketertiban dan kepastian hukum, yang mensyaratkan materi muatan undang-undang harus dapat mewujudkan ketertiban dalam masyarakat melalui jaminan kepastian hukum.

DPR dalam membentuk atau merancang Undang-Undang seharusnya harus berdasarkan konstitusi sebagai hukum dasar atau sumber hukum bagi pembentukan peraturan perundang-undangan. Lembaga pembentuk peraturan perundang-undangan harus mengacu pada azas-azas pembentukan peraturan perundang-undangan yang terdapat dalam Pasal 5 dan Pasal 6 Undang-Undang Nomor 12 Tahun 2011 tentang Pembentukan Peraturan Perundang-undangan.

2. Kekuatan Mengikat Putusan Mahkamah Konstitusi Nomor 24/PUUXVII/2019

Sebagaimana telah tercantum dalam Pasal 24C ayat (1) UndangUndang Dasar Tahun 1945 menyatakan bahwa "Mahkamah Konstitusi berwenang mengadili pada tingkat pertama dan terakhir yang putusannya bersifat final untuk menguji undang-undang...". Putusan bersifat final artinya putusan Mahkamah Konstitusi langsung memperoleh kekuatan hukum tetap sejak diucapkan dan tidak ada upaya hukum yang dapat ditempuh (Pasal 10 ayat (1) Undang-Undang Mahkamah Konstitusi). 
Sifat final dalam putusan Mahkamah Konstitusi dalam UndangUndang Mahkamah Konstitusi mencakup pula kekuatan hukum mengikat (final and binding). Sifat mengikat bermakna putusan Mahkamah Konstitusi tidak hanya berlaku pada para pihak atau pemohon tetapi bagi seluruh masyarakat Indonesia.

Kekuatan mengikat Putusan Mahkamah Konstitusi sejak selesai diucapkan di dalam sidang pleno terbuka untuk umum sebagaimana tercantum dalam Pasal 47 Undang-Undang Nomor 8 Tahun 2011 Mahkamah Konstitusi.

Putusan Mahkamah Konstitusi Nomor 24/PUU-XVII/2019 yang menyatakan bahwa materi muatan ayat, pasal dan/atau bagian undangundang bertentangan dengan Undang-Undang Dasar Negara Republik Indonesia Tahun 1945, maka materi muatan ayat, pasal dan/atau bagian undang-undang tersebut tidak mempunyai kekuatan hukum mengikat. Karena tidak ada kejelasan tujuan tentang ayat, pasal dan/atau bagian undang-undang tersebut maka oleh Mahkamah Konstitusi dikatakan materi muatan tersebut inkonstitusional.

\section{G. Kesimpulan}

1. Pelaksanaan Putusan MK Nomor 09/PUU-VII/2009 dan Putusan MK Nomor 24/PUU-XII/2014 tidak efektif dan tidak dapat dilaksanakan sebagaimana mestinya. Akibat ketidak patuhan atau tidak efektivnya Putusan Mahkamah Konstitusi dengan kembali berlakunya ketentuan pasalpasal yang diuji oleh Mahkamah Konstitusi tersebut menyebabkan ketidakpastian hukum.

2. Putusan Mahkamah Konstitusi Nomor 24/PUU-XVII/2019 yang menyatakan bahwa materi muatan ayat, pasal dan/atau bagian undangundang bertentangan dengan Undang-Undang Dasar Negara Republik Indonesia Tahun 1945, maka materi muatan ayat, pasal dan/atau bagian undang-undang tersebut tidak mempunyai kekuatan hukum mengikat. Karena tidak ada kejelasan tujuan tentang ayat, pasal dan/atau bagian undang-undang tersebut.

\section{H. Saran}

1. Menurut penulis, lembaga pembentuk undang-undang perlu memperkuat kewenangan hak menguji dan menjamin adanya peningkatan efektivitas putusan lembaga kehakimah terutama dengan penyatuatapan mekanisme judicial review yang dilakukan oleh Mahkamah Konstitusi.

2. Putusan Mahkamah Konstitusi yang bersifat final dan mengikat sendiri tidak;ah dipatuhi karena tidak diundangkannya putusan-putusan tersebut ke dalam Lembaran Negara sebagai legalitas suatu peraturan yang dibuat oleh lembaga kekuasaan kehakiman, agar putusan tersebut dapat dilaksanakan dan dipatuhi demi terciptanya ketertiban melalui kepastian hukum. 


\section{DAFTAR PUSTAKA}

\section{A. Buku :}

Abdul Latif, Buku Ajar Hukum Acara Mahkamah Konstitusi, Total Media, Yogyakarta, 2009.

Fakultas Hukum Universitas Majalengka, Panduan Skripsi, Fakultas Hukum Universitas Majalengka, Majalengka, 2019.

Imam Soebechi, Hak Uji Materiil, Sinar Grafika, Jakarta, 2016.

Jimly Asshiddiqie, Hukum Acara Pengujian Undang-Undang, Konstitusi Press, Jakarta, 2006.

Jimly Asshiddiqie, Model-model Pengujian Konstitusional di Berbagai Negara, Konstitusi Press, Jakarta, 2013.

M. Laica Marzuki, Berjalan di Ranah Hukum, Konstitusi Press, Jakarta, 2005.

Muhamad Rakhmat, Konstitusi dan Kelembagaan Negara, Logoz Publishing, Bandung, 2014.

Sihajuddin dan Winardi, Dasar-dasar Hukum Tata Negara Indonesia, Setara Press, Malang, 2015.

Sumali, Reduksi Kekuasaan Eksekutif Di Bidang Peraturan Pengganti Undang-Undang (PERPU), UMM Press, Malang, 2002.

\section{B. Peraturan Perundang-undangan}

Undang-Undang Dasar Negara Republik Indonesia Tahun 1945.

Undang-Undang Nomor 48 Tahun 1985 tentang Mahkamah Agung.

Undang-Undang Nomor 12 Tahun 2011 Tentang Pembentukan Peraturan Perundang-undangan.

\section{Sumber Lain:}

\section{Internet}

Abi Jam'an Kurnia, Uji Materiil dan Uji Formil, diakses dari www.hukumonline.com, pada tanggal 15 November 2019, pukul 08.35.

Cahyo Dwi Nugrahanto, Hak Uji Materiil Oleh Kekuasaan Kehakiman (Judicial Review) terhadap Peraturan menteri Oleh Mahkamah Agung 
Republik Indonesia, diakses dari https://digilib.uns.ac.id /dokumen/ download/27657/NTg1MjA=/Hak-Uji-Materiil, pada tanggal 11 November 2019, pukul 12.13.

Diakses dari https://id.wikipedia.org/wiki/Pengujian_yudisial, diakses pada tanggal 31 Oktober 2019, pukul 14.04.

Diakses dari https://www.slideshare.net/Meehawk/teori-konstitusi-35464074, pada tanggal 26 November 2019, pukul 20.39.

Janpatar Simamora, Analisa Yuridis terhadap Model Kewenangan Judicial Review di Indonesia, diakses dari https://media.neliti.com/ media/ publications/40754-analisa-yuridis-terhadap-model-kewenangabe76111e.pdf, pada tanggal 02 November 2019, pukul 11.53.

Khunti Dyah Wardani, Impechment Dalam Konstitusi Indonesia, diakses dari https://dspace.uii.ac.id, Loc.Cit.

Khunti Dyah Wardani, Impechment Dalam Konstitusi Indonesia, UII Press, Yogyakarta, diakses dari https://dspace.uii.ac.id, pada tanggal 18 November 2019, pukul 21.28.

Putusan Mahkamah Konstitusi Nomor 24/PUU-XVII/2019, diakses dari https://mkri.id/public/content/persidangan/putusan/putusan_mkri_5363 .pdf, pada tanggal 02 November 2019, pukul 11.46.

Ronny Hanitijo Soemitro dikutip oleh Elviandri, Metodologi Penelitian Hukum dan Jurimetri, Ghalia Indonesia, Jakarta, 1990, http://eprints.ums.ac.id/6751/1/R100040049.pdf, diakses di internet pada tanggal 31 Oktober 2019, pada pukul 15.33.

Sudikno Mertokusumo,diakses dari http://studihukum. blogspot.com/2010/12/ urgensi-partisipasi-publik-dalam.html, pada tanggal 02 November 2019, pukul 12.56 .

Tanicha Aprilia dan Ditho Nugraha, Lembaga Negara Fungsi dan Wewenangnya, diakses dari http://kuliahpublik.blogspot .com/2015/ 04/teori-institusional.html, pada tanggal 11 November 2019, pukul 20.10 . 